\title{
SARS-CoV-2 Infection Is Associated with Vitamin D Deficiency in Côte d'Ivoire
}

\author{
Lydie Boyvin 1,2, Yapi Guillaume Yayé3, Gnogbo Alexis Bahi1,2, \\ Aya Jeanne Armande Aké2, Kipré Laurent Séri1,2, Daouda Sévédé4, \\ Serge Eholié5, Mireille Dosso4, Allico Joseph Djaman1,2* (i)
}

${ }^{1}$ Department of Fundamental \& Medical Biochemistry, Institut Pasteur of Côte d'Ivoire (IPCI), Abidjan, Côte d'Ivoire ${ }^{2}$ Biology and Health Laboratory, University Félix Houphouët-Boygny (UFHB), Abidjan, Côte d’Ivoire ${ }^{3}$ Department of Biochemistry-Microbiology, University of Jean Lorougnon Guédé, Daloa, Côte d'Ivoire ${ }^{4}$ Department of Bacteriology-Virology, Institut Pasteur of Côte d'Ivoire (IPCI), Abidjan, Côte d'Ivoire ${ }^{5}$ Department of Infectious Diseases of the Treichville University Hospital Center, Abidjan, Côte d'Ivoire Email: ^djamanj@yahoo.fr

How to cite this paper: Boyvin, L., Yayé, Y.G., Bahi, G.A., Aké, A.J.A., Séri, K.L., Sévédé, D., Eholié, S., Dosso, M. and Djaman, A.J. (2022) SARS-CoV-2 Infection Is Associated with Vitamin D Deficiency in Côte d'Ivoire. Advances in Microbiology, $12,43-52$

https://doi.org/10.4236/aim.2022.122004

Received: January 3, 2022

Accepted: February 8, 2022

Published: February 11, 2022

Copyright $\odot 2022$ by author(s) and Scientific Research Publishing Inc. This work is licensed under the Creative Commons Attribution International License (CC BY 4.0).

http://creativecommons.org/licenses/by/4.0/

\begin{abstract}
In 2019, the coronavirus pandemic broke out as a serious public health issue worldwide. In Côte d'Ivoire, the number of cases of COVID-19 has increased rapidly. The Severe Acute Respiratory Syndrome virus (SARS-CoV-2) binds to angiotensin converting enzyme 2 (ACE2) receptors in the respiratory tracts and enters the respiratory and alveolar cells of infected patients. Deficiency of fat-soluble vitamin $\mathrm{D}_{3}$ is associated with respiratory distress syndrome and pulmonary fibrosis by activation of the renin-angiotensin system. In Côte d'Ivoire, very little research is being done on SARS-CoV-2 and vitamin D. The objective of this study was to assess the vitamin D status of people infected and suffering from COVID-19 in order to contribute to their medical treatment. The study involved 100 adults infected with SARS-CoV-2 (24 women and $76 \mathrm{men})$. After confirmation of the patient's SARS-CoV-2 status by RT-PCR, the $25(\mathrm{OH})$ vitamin D assay was performed on the Cobas 6000 device and compared to control subjects, the non-COVID-19 positive. A significant decrease in 25-hydroxy vitamin $\mathrm{D}_{3}$ concentrations $(44 \pm 1.29 \mathrm{nmole} / \mathrm{L})$ was observed in patients infected with SARS-CoV-2, compared to control (78 $\pm 0.68 \mathrm{nmole} / \mathrm{L})(\mathrm{p}<0.0001)$. The 25 -hydroxy vitamin $\mathrm{D}_{3}$ deficiency requires vitamin $\mathrm{D}$ supplementation in the management of hospitalized patients infected with SARS-CoV-2.
\end{abstract}

\section{Keywords}

Côte d'Ivoire, SARS-CoV-2, Vitamin D Deficiency 


\section{Introduction}

SARS-CoV-2 infection is a public health problem that has infected 314,207,645 million people since January 12, 2022, and killed 5,521,807 million worldwide [1] [2]. The high mortality rate primarily concerned people who already had other chronic diseases. In Africa, 3.7 million people are infected with SARS-CoV-2 with a low mortality rate while the impact of the pandemic remains uncertain [3]. In Côte d'Ivoire, 21,485 confirmed cases of Coronavirus were recorded, including 21,109 cured, 244 under treatment and 132 deaths according to national public health communications (unpublished data).

During COVID-19 infection, SARS-CoV-2 virus binds to angiotensin converting enzyme 2 (ACE2) receptors in the respiratory tracts of infected patients, to enter respiratory and alveolar cells [4] [5] and uses the TMPRSS2 serine protease for host cell priming. The ACE2 receptor is primarily expressed by epithelial cells in blood vessels, intestine, lungs, kidneys and heart [6] [7]. Type II pneumocytes, on which the ACE2 receptors are strongly expressed, represent the main target of SARS-CoV [8] [9].

Vitamin $\mathrm{D}$ is a fat-soluble hormone that possesses a wide range of activities: immunomodulatory, anti-inflammatory, antifibrotic and antioxidant [10]. Its receptors (VDRs) are widely distributed in respiratory epithelial cells and immune cells (B-lymphocytes, $\mathrm{T}$ lymphocytes, macrophages and monocytes). The enzyme, $1 \alpha$-Hydroxylase or CYP27B1 is required for the transformation of the major circulating form of vitamin D (25-hydroxy vitamin D (25 (OH) D), into its active form (1,25-dihydroxy vitamin $\mathrm{D}$ or calcitriol) in the bronchial epithelium and immune cells [11]. The active form 1,25-dihydroxy vitamin D, has shown protective effects against severe lung damage by modulating the expression of members of the renin-angiotensin system such as ACE2 in lung tissue, supporting the role of vitamin D deficiency as a pathogenic factor for COVID-19 [12] [13]. The $1 \alpha$-Hydroxylase, induced by various stimuli, including cytokines and toll-like receptor ligands in the respiratory tract, suppresses SARS-CoV-2 replication by blocking membrane fusion [14]. However, adequate serum 25 $(\mathrm{OH}) \mathrm{D}$ levels are needed to increase 1,25-dihydroxy vitamin D levels and thus improve the immune response to respiratory viral infections [15].

In Côte d'Ivoire, few studies have been conducted on vitamin $\mathrm{D}$ and SARS-CoV-2 virus in COVID-19 patients. The main objective of this study was to determine the 25-hydroxy vitamin $\mathrm{D}_{3}$ status in patients infected with SARS-CoV-2.

\section{Material and Methods}

\subsection{Type of Study}

This is a descriptive cross-sectional case-control study carried out from May 2020 to October 2020 at the Department of Fundamental and Medical Biochemistry of the Pasteur Institute of Côte d'Ivoire (IPCI) for the assay of biochemi- 
cal parameters and in the service of infectious diseases at the University Hospital of Treichville (SMIT) for the recruitment of hospitalized patients infected with SARS-CoV-2. Control subjects consisted of SARS-CoV-2 negative people.

\subsection{Biological and Technical Material}

Fasting venous blood samples were collected from 100 adult patients infected with SARS-CoV-2 (24 women and 76 men), hospitalized in the Infectious Diseases Department of the University Hospital of Treichville (Abidjan). One hundred blood samples (dry tubes without anticoagulant) from SARS-CoV-2 negative adults of the controls ( 50 females and 50 males) were also used for the performance of various biochemical analyses.

Sera obtained after centrifugation at $3000 \mathrm{rpm} / \mathrm{min}$ for $5 \mathrm{~min}$ from dry tubes were used for biochemical tests and for the determination $25(\mathrm{OH})$ vitamin D. The rest of the serum samples were stored at $-20^{\circ} \mathrm{C}$ for future use.

Elders, pregnant women, children and patients on vitamin $\mathrm{D}$ were not included in this study.

\subsection{Methods}

Rapid RT-PCR (Reverse Transcriptase Polymerase Chain Reaction) tests were performed to diagnose SARS-CoV-2 virus. This method relies on real-time technologies that use fluorescent markers and constantly monitor the fluorescence emitted by amplification products. The fluorescence of the sample increases in proportion to the number of viral copies produced.

The 25-hydroxyvitamin $\mathrm{D}_{3}$ assay, the principle of which is immunological investigation through electro-chemiluminescence, was carried out on the COBAS 6000 automatic device. The resulting light intensity constitutes the analytical signal which is directly proportional to the number of luminophores present [16].

The assay of biochemical parameters such as CRP, Orosomucoid, creatinine, urea, glycemia, transaminases, etc. were carried out on the COBAS C311 HITACHI device, which is based on enzymatic and colorimetric methods which use a chromogen. The intensity of the coloration developed is directly proportional to the concentration of the substance assayed [17].

\subsection{Data Analysis}

Statistical analysis was performed using Graph Pad Prism 8.0 software. The student $\mathrm{t}$-test made it possible to calculate and compare the means. The degree of significance was set at $5 \%$.

\section{Material and Methods}

\subsection{Epidemiological Characteristics of the Study Population}

This study involved 100 blood samples from patients infected with SARS-CoV-2 (76 men; 24 women) and uninfected control sample (50 men; 50 women). 
The mean of infected patients was $54 \pm 3.42$ years with extremes of 23 to 85 years, compared to that of uninfected control, at $33 \pm 0.84$ years with extremes of 18 to 49 years $(\mathrm{p}<0.0001)$.

\subsection{Vitamin D Status of the Study Population}

In the general population studied, the average vitamin $\mathrm{D}$ value in infected patients was significantly lower $(44 \pm 1.29 \mathrm{nmole} / \mathrm{L})$ than in control $(78 \pm 0.68$ nmole/L) $(\mathrm{p}<0.0001)$.

Mean values of vitamin $\mathrm{D}$ were significantly lower in infected men $(47 \pm 1.55$ nmole/L) and women $(39 \pm 2.02 \mathrm{nmole} / \mathrm{L})$ than in control men and women $(78$ $\pm 0.96 \mathrm{nmole} / \mathrm{L})(\mathrm{p}<0.0001)$.

Eighty-nine percent of patients ( $71 \%$ deficient and $18 \%$ insufficient) infected with SARS-CoV-2 against forty-three percent of control (10\% deficient and 33\% Insufficient) presented with deficiency and insufficiency of vitamin $\mathrm{D}$ (Table 1).

Of the 100 patients infected with SARS-CoV-2, 71 developed 25-hydroxy vitamin $\mathrm{D}_{3}$ deficiency $(<52 \mathrm{nmole} / \mathrm{L})$. An insufficiency $(52-78 \mathrm{nmole} / \mathrm{L})$ of 25-hydroxyvitamin $\mathrm{D}_{3}$ was observed in 18 patients. 11 patients, all males, presented normal mean values ( $\geq 78 \mathrm{nmole} / \mathrm{L}$ ) of $25-\mathrm{OH}$ vitamin $\mathrm{D}_{3}$ (Figure 1 ).

Fifty-eight out of one hundred (58/100) patients with a history of pathology (renal, hepatic, pancreatic) had lower mean vitamin D values $(42 \pm \mathrm{nmole} / \mathrm{L})$ than those $(57 \pm \mathrm{nmole} / \mathrm{L})$ with no pathological history without significant difference $(\mathrm{p}<0.0633)$ (Table 2).

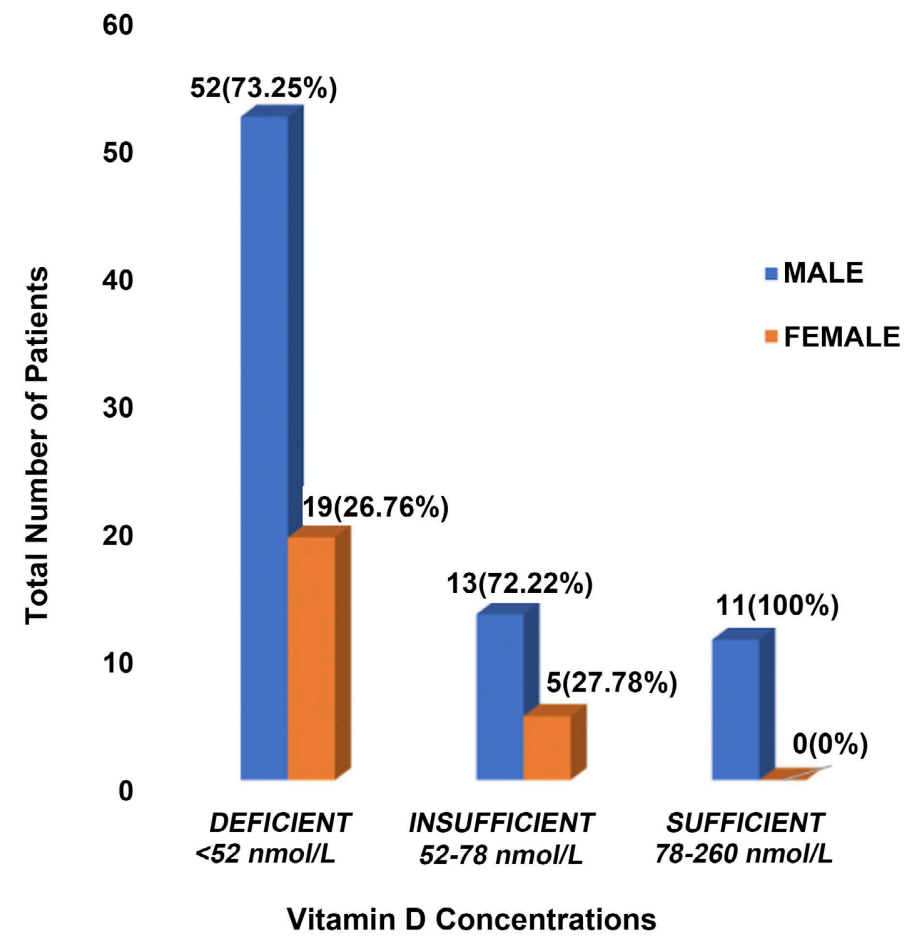

Figure 1. Distribution of SARS-CoV-2 patients according to sex and vitamin D status. 
Table 1. Distribution of the study population according to vitamin D status.

\begin{tabular}{|c|c|c|c|c|c|c|}
\hline \multirow{3}{*}{$25(\mathrm{OH}) \mathrm{D} 3$} & \multicolumn{3}{|c|}{ COVID-19 Negative Control } & \multicolumn{3}{|c|}{ COVID-19 Positive Patients } \\
\hline & \multicolumn{3}{|c|}{ Number } & \multicolumn{3}{|c|}{ Number } \\
\hline & $\begin{array}{c}\text { Male } \\
(n=50)\end{array}$ & $\begin{array}{l}\text { Female } \\
(n=50)\end{array}$ & $\begin{array}{c}\text { Total } \\
(\mathrm{n}=100)\end{array}$ & $\begin{array}{c}\text { Male } \\
(n=76)\end{array}$ & $\begin{array}{l}\text { Female } \\
(n=24)\end{array}$ & $\begin{array}{c}\text { Total } \\
(n=100)\end{array}$ \\
\hline $\begin{array}{c}\text { Deficient } \\
(52 \mathrm{nmole} / \mathrm{L})\end{array}$ & $\begin{array}{c}5 \\
(50 \%)\end{array}$ & $\begin{array}{c}5 \\
(50 \%)\end{array}$ & $\begin{array}{c}10 \\
(100 \%)\end{array}$ & $\begin{array}{c}52 \\
(73.24 \%)\end{array}$ & $\begin{array}{c}19 \\
(26.76 \%)\end{array}$ & $71(100 \%)$ \\
\hline $\begin{array}{c}\text { Insufficient } \\
(52-78 \mathrm{nmole} / \mathrm{L})\end{array}$ & $\begin{array}{c}18 \\
(54.55 \%)\end{array}$ & $\begin{array}{c}15 \\
(45.45 \%)\end{array}$ & $\begin{array}{c}33 \\
(100 \%)\end{array}$ & $\begin{array}{c}13 \\
(72.22 \%)\end{array}$ & $\begin{array}{c}\mathbf{5} \\
(27.78 \%)\end{array}$ & $\begin{array}{c}18 \\
(100 \%)\end{array}$ \\
\hline $\begin{array}{c}\text { Sufficient } \\
(78-260 \text { nmole/L) }\end{array}$ & $\begin{array}{c}27 \\
(47.37 \%)\end{array}$ & $\begin{array}{c}30 \\
(52.63 \%)\end{array}$ & $\begin{array}{c}57 \\
(100 \%)\end{array}$ & $\begin{array}{c}11 \\
(100 \%)\end{array}$ & $\begin{array}{c}0 \\
(0 \%)\end{array}$ & $\begin{array}{c}11 \\
(100 \%)\end{array}$ \\
\hline
\end{tabular}

Table 2. Breakdown of COVID-19 patients according to pathological history.

\begin{tabular}{|c|c|c|c|}
\hline & \multicolumn{2}{|c|}{ Mean Value of COVID-19 Patients } & \multirow{2}{*}{$\mathrm{P}$ Value $\mathrm{p}<0.05$} \\
\hline & With History Pathologic $(n=58)$ & Without History Pathologic $(n=42)$ & \\
\hline \multicolumn{4}{|l|}{ Vitamin D } \\
\hline Sufficient $78-260 \mathrm{nmol} / \mathrm{L}$ & & & 0.0633 \\
\hline \multicolumn{4}{|l|}{ Insufficient $52-78 \mathrm{nmol} / \mathrm{L}$} \\
\hline Deficient $<52 \mathrm{nmol} / \mathrm{L}$ & & & \\
\hline $\begin{aligned} \text { CRP } \\
\text { Ref. }<6 \mathrm{mg} / \mathrm{L}\end{aligned}$ & $60 \pm 70.16$ & $24 \pm 28.12$ & 0.0505 \\
\hline \multicolumn{4}{|l|}{ Orosomucoïde } \\
\hline $\begin{array}{c}\text { Ref.: M: } 0.52-1.25 \mathrm{~g} / \mathrm{L} \\
\text { F: } 0.48-1.29 \mathrm{~g} / \mathrm{L}\end{array}$ & $1.57 \pm 0.46$ & $1.12 \pm 0.44$ & 0.0045 \\
\hline $\begin{array}{c}\text { Total Cholesterol } \\
\text { Ref.: } 2.74-6.45 \mathrm{mmol} / \mathrm{L}\end{array}$ & $4.64 \pm 0.11$ & $4.22 \pm 0.24$ & 0.5877 \\
\hline $\begin{array}{c}\text { HDL Cholesterol } \\
\text { Ref.:1.04 - } 1.81 \mathrm{mmol} / \mathrm{L}\end{array}$ & $1.14 \pm 0.03$ & $1.14 \pm 0.07$ & 0.9418 \\
\hline $\begin{array}{l}\text { LDL Cholesterol } \\
\text { Ref.: }<4.14 \mathrm{mmol} / \mathrm{L}\end{array}$ & $2.43 \pm 0.09$ & $2.69 \pm 0.18$ & 0.6514 \\
\hline $\begin{array}{c}\text { Creatinin } \\
\text { Ref.: } 44-106 \mu \mathrm{mol} / \mathrm{L}\end{array}$ & $159 \pm 6.29$ & $80 \pm 0.63$ & 0.2213 \\
\hline $\begin{array}{c}\text { Urea } \\
\text { Ref.: } 1.67-5.83 \mathrm{mmol} / \mathrm{L}\end{array}$ & $9.33 \pm 0.18$ & $3.72 \pm 0.03$ & 0.1106 \\
\hline $\begin{array}{c}\text { Glycemia } \\
\text { Ref.: } 4.16-6.11 \mathrm{mmol} / \mathrm{L}\end{array}$ & $9.66 \pm 0.30$ & $5.44 \pm 0.09$ & 0.1488 \\
\hline $\begin{array}{c}\text { TGP/ALAT } \\
\text { Ref.: } 8 \text { - } 49 \text { UI/L }\end{array}$ & $68 \pm 8.86$ & $28 \pm 2.88$ & 0.0006 \\
\hline $\begin{array}{c}\text { TGO/ASAT } \\
\text { Ref.: } 8 \text { - } 49 \text { UI/L }\end{array}$ & $82 \pm 14.93$ & $32 \pm 4.66$ & 0.0078 \\
\hline $\begin{array}{c}\text { Lipase } \\
\text { Ref.: } 12-62 \mathrm{UI} / \mathrm{L}\end{array}$ & $106 \pm 22.32$ & $33.69 \pm 3.374$ & 0.0085 \\
\hline
\end{tabular}




\section{Discussion}

SARS-CoV-2 infection affects, on the average, a predominantly male population above 50. People at this age have an immune system very often weakened by underlying chronic diseases, which favors the multiplication of the coronavirus [18]. The male predominance can be explained by a higher concentration of ACE2 in the plasma of men than in women [19]. In fact, the angiotensin converting enzyme 2 (ACE2: or angiotensin) is a functional receptor for coronavirus and the portal of entry for the coronavirus into the plasma membrane of a cell, but this enzyme can also be in a free form, circulating in the blood plasma [19].

Vitamin D deficiency in the seniors could lead to the development of a severe form of the disease. Indeed, 1,25 dihydroxy vitamin $\mathrm{D}_{3}$ has shown protective effects against severe lung damage by modulating the expression of ACE2 of the renin-angiotensin system in lung tissue, supporting the role of vitamin D deficiency as a pathogenic factor of COVID-19 [12].

In addition, Zdrenghea's studies in Romania showed positive associations between circulating $25(\mathrm{OH}) \mathrm{D}$ concentration and lung function [20]. Vitamin D supplementation may be especially important for senior people, as they are at high risk of complications from COVID-19 and vitamin D deficiency [18].

Eighty-nine percent (89\%) of the patients infected with SARS-CoV-2 had insufficiency and deficiency of Vitamin D. These results are similar to those of Kauffmann, who showed a higher positivity rate of SARS-CoV-2 in $25(\mathrm{OH}) \mathrm{D}$ deficient patients. The risk of SARS-CoV-2 positivity continued to decrease until serum levels reached $55 \mathrm{ng} / \mathrm{mL}$ [21].

Forty-three percent (43\%) of the uninfected control patients in this study presented a $25(\mathrm{OH})$ vitamin $\mathrm{D}$ deficiency, despite the residing in a very sunny country. Indeed, the main source of absorption of vitamin D is skin synthesis through ultraviolet sun rays, while the second source is food. This deficit may be due to a diet poor in vitamin $\mathrm{D}$, lacking in milk and dairy products, fish, eggs and a high prevalence of infectious diseases in developing countries [22] [23]. Excessive exposure to the sun is also carcinogenic. Other factors such as female gender, age, dark pigmentation of the skin, gastrointestinal-intestinal absorption disorders, risk factors for non-communicable diseases, etc. are associated with vitamin D deficiency [23].

Fifty-eight percent of the patients in this study with renal, diabetic and hepatic history presented a more pronounced deficiency. This could be explained by the fact that the impact on the regulation of inflammation is particularly important in the seniors, obese and those with chronic diseases, as they may be pre-disposed to a greater inflammatory response, if they are exposed to COVID-19 [24]. Indeed, in humans, a decrease in circulating 25 -hydroxy-vitamin D is associated with an increased activity of the Renin Angiotensin System (RAS) and an increase in blood pressure (hypertension) [25]. Any deleterious effects associated with SARS-CoV-2 infection in humans (i.e. nervous disorders/headaches, breathing difficulty, heart problems, loss of smell (anosmia), loss of taste (ageusia), thrombosis, diarrhea, dermatitis, etc.) depend on the over-reaction of RAS 
induced by SARS-CoV-2 and vitamin D deficiency.

Overall, it is clear that RAS and vitamin D play a major role in the infection of humans with SARS-CoV-2 and the associated diseases COVID-19 [6] [26]. The other symptoms/diseases of COVID-19, known or anticipated (not described to date), linked to the action of SARS-CoV-2 on the RAS [27] are high blood pressure, chronic kidney disease, asthma, pulmonary disease, type 2 diabetes, obesity and liver disease [6].

It is obvious that vitamin D plays an important role in the therapeutic management of patients suffering from COVID-19; however other approaches such as photo-biomodulation therapy are currently being investigated. For example, PDT with Phtalomethyl D stimulates the healing/repair and immunomodulation processes during viral infection [28].

\section{Conclusion}

This study showed $25(\mathrm{OH}) \mathrm{D}_{3}$ deficiency and elevated levels of CRP and orosomucoid in COVID-19 positive patients, which are more pronounced in people with a medical history. Vitamin D supplementation is essential in the treatment and management of hospitalized patients infected with SARS-CoV-2.

\section{Acknowledgements}

We express our sincere gratitude to the Head of the Infectious Diseases Department and staff of the University Hospital of Treichville, and to the director and staff of the Institut Pasteur Côte of d'Ivoire in Abidjan for their cooperation in the conduct of this research.

\section{Authors' Contribution}

This work was carried out by collaboration of all the authors. Author LB wrote the study protocol, the first draft of the manuscript, and monitored the technical aspects of the study. Authors GAB and SD supervised the collection of blood samples and managed the laboratory tests for the study. Authors KLS and AAJA supervised the analyses and performed the statistical analyses of the study. Authors YGY, ES and MD managed part of the references research and edited the first draft of the manuscript. Author JAD designed the study, managed part of the literature research and the final editing of the manuscript. All authors have read and approved the final version of the manuscript.

\section{Ethical Considerations}

For the research, consent from individuals was obtained for the use of their collected blood samples.

\section{Conflicts of Interest}

The authors declare no conflicts of interest regarding the publication of this paper. 


\section{References}

[1] Elflein, J. (2021) Number of Coronavirus (COVID-19) Cases Worldwide as of Janvier 12, 2021, by Country. Statista. https://www.statista.com/statistics/1043366/novel-coronavirus-2019ncov-cases-wor ldwide-by-country/

[2] Elflein, J. (2021) Number of Novel Coronavirus (COVID-19) Deaths Worldwide as of December 16, 2021, by Country. Statista.

https://www.statista.com/statistics/1093256/novel-coronavirus-2019ncov-deaths-wo rldwide-by-country/

[3] Caramel, L. (2021) En Afrique, l'ampleur de l'épidémie de COVID-19 reste une grande inconnue. Le Monde Afrique. https://www.lemonde.fr

[4] Lan, J., Ge, J.W., Yu, J.F., Shan, S.S., Zhou, H., Fan, S.L., Zhang, Q., Shi, X.L., Wang, Q.S., Zhang, L.Q. and Wang, X.Q. (2020) Structure of the SARS-CoV-2 Spike Receptor-Binding Domain Bound to the ACE2 Receptor. Nature, 581, 215-220. https://doi.org/10.1038/s41586-020-2180-5

[5] Wan, Y.S., Shang, J., Graham, R., Baric, R.S. and Li, F. (2020) Receptor Recognition by the Novel Coronavirus from Wuhan: An Analysis Based on Decade-Long Structural Studies of SARS Coronavirus. Journal of Virology, 94, e00127-120.

[6] Cao, Z., Wu, Y., Faucon, E. and Sabatier, J.M. (2020) SARS-CoV-2 \& COVID-19: Key-Roles of the 'Renin-Angiotensin' System/Vitamin D Impacting Drug and Vaccine Developments. Infectious Disorders-Drug Targets, 20, 348-349. https://doi.org/10.2174/1871526520999200505174704

[7] Ziegler, C.G.K., Allon, S.J., Nyquist, S.K., et al. (2020) SARS-CoV-2 Receptor ACE2 Is an Interferon-Stimulated Gene in Human Airway Epithelial Cells and Is Detected in Specific Cell Subsets across Tissues. Cell, 181, 1016-1035.E19. https://doi.org/10.1016/j.cell.2020.04.035

[8] Bombardini, T. and Picano, E. (2020) Angiotensin-Converting Enzyme 2 as the Molecular Bridge between Epidemiologic and Clinical Features of COVID-19. Canadian Journal of Cardiology, 36, 784.E1-784.E2. https://doi.org/10.1016/j.cjca.2020.03.026

[9] Craveiro, V., Cabral, M. and Araújo, J. (2018) Association de la concentration sérique de 25-hydroxy vitamine $\mathrm{D}$ avec la fonction pulmonaire chez les jeunes adultes. Nutrients, 10, Article No. 1728. https://doi.org/10.3390/nu10111728

[10] Carlberg, C. (2014) The Physiology of Vitamin D-Far More than Calcium and Bone. Frontiers in Physiology, 5, Article No. 335. https://doi.org/10.3389/fphys.2014.0033

[11] Pfeffer, P.E. and Hawrylowicz, C.M. (2012) Vitamin D and Lung Disease. Thorax, 67, 1018-1020. https://doi.org/10.1136/thoraxjnl-2012-202139

[12] Xu, J., Yang, J.L., Chen, J., Luo, Q.L., Zhang, Q. and Zhang, H. (2017) Vitamin D Alleviates Lipopolysaccharide-Induced Acute Lung Injury via Regulation of the Renin-Angiotensin System. Molecular Medicine Reports, 16, 7432-7438. https://doi.org/10.3892/mmr.2017.7546

[13] Ebadi, M. and Montano-Loza, A.J. (2020) Perspective: Improving Vitamin D Status in the Management of COVID-19. European Journal of Clinical Nutrition, 74, 856-859. https://doi.org/10.1038/s41430-020-0661-0

[14] Zang, R., Case, J.B, Yutuc, E., Ma, X., Shen, S., Gomez Castro, M.F. Liu, Z., Zeng, Q., Zhao, H., Son, J., Rothlauf, P.W., Kreutzberger, A.J.B., Hou, G., Zhang, H., Sayantan, B., Wang, X., Vahey, M.D., Mani, K., Griffiths, W.J., Kirchhausen, T., Fremont, D.H., Guo, H., Diwan, A., Wang, Y., Diamond, M.S., Whelan, S.P.J. and 
Ding, S. (2020) Cholesterol 25-Hydroxylase Suppresses SARS-CoV-2 Replication by Blocking Membrane Fusion. Proceedings of the National Academy of Sciences of the United States of America, 117, 32105-32113. https://doi.org/10.1073/pnas.2012197117

[15] Greiller, C.L. and Martineau, A.R. (2015) Modulation of the Immune Response to Respiratory Viruses by Vitamin D. Nutrients, 7, 4240-4270.

https://doi.org/10.3390/nu7064240

[16] Souberbielle, J.C., Massart, C., Brailly-Tabard, S., Cavalier, E. and Chanson, P. (2016) Prevalence and Determinants of Vitamin D Deficiency in Healthy French Adults: The VARIETE Study. Endocrine, 53, 543-550. https://doi.org/10.1007/s12020-016-0960-3

[17] Deyhimi, F., Arabieh, M. and Parvin, L. (2006) Optimization of the Emerson-Trinder Enzymatic Reaction by Response Surface Methodology. Biocatalysis and Biotransformation, 24, 263-271. https://doi.org/10.1080/10242420600661943

[18] Mitchell, F. (2020) Vitamin-D and COVID-19: Do Deficient Risk a Poorer Outcome? Lancet Diabetes Endocrinology, 8, 570. https://doi.org/10.1016/S2213-8587(20)30183-2

[19] Sama, I.E., Ravera, A., Santema, B.T., van Goor, H., Ter Maaten, J.M., Cleland, J.G.F., Rienstra, M., Friedrich, A.W., Samani, N.J., Leong, L. Ng., Dickstein, K., Lang, C.C., Filippatos, G., Anker, S.D., Ponikowski, P., Metra, M., van Veldhuisen, D.J. and Voors, A.A. (2020) Circulating Plasma Concentrations of Angiotensin-Converting Enzyme 2 in Men and Women with Heart Failure and Effects of Renin-Angiotensin-Aldosterone Inhibitors. European Heart Journal, 41, 1810-1817. https://doi.org/10.1093/eurheartj/ehaa373

[20] Zdrenghea, M.T., Makrinioti, H., Bagacean, C., Bush, A., Johnston, S.L. and Stanciu, L.A. (2017) Vitamin D Modulation of Innate Immune Responses to Respiratory Viral infections. Reviews in Medical Virology, 27, e1909. https://doi.org/10.1002/rmv.1909

[21] Kaufman, H.W., Niles, J., Kroll, M.H., Bi, C. and Holick, M.F. (2020) SARS-CoV-2 Positivity Rates Associated with Circulating 25-Hydroxy Vitamin D Levels. PLoS ONE, 15, e0239252. https://doi.org/10.1371/journal.pone.0239252

[22] Bouillon, R. (2020) Vitamin D Status in Africa Is Worse than in Other Continents. Lancet Global Health, 8, E20-E21. https://doi.org/10.1016/S2214-109X(19)30492-9

[23] Mogire, R.M., Mutua, A., Kimita, W., Kamau, W., Bejon, P., Pettifor J.M., Adeyemo, A., Williams, T.N. and Atkinson, S.H. (2020) Prevalence of Vitamin D Deficiency in Africa: A Systematic Review and Meta-Analysis. Lancet Global Health, 8, E134-E142. https://doi.org/10.1016/S2214-109X(19)30457-7

[24] Laird, E., Rhodes, J. and Kenny, R.A. (2020) Vitamin D and Inflammation: Potential Implications for Severity of COVID-19. Iranian Medical Journal, 113, 81.

[25] Leung, P.S. (2019) L'action modulatrice de la vitamine D sur le système rénine-angiotensine et la détermination de la résistance hépatique à l'insuline. $\mathrm{Mo}$ lecules, 24, 2479-2482.

[26] Martín Gimenez, V.M., Inserra, F., Ferder L., García, J. and Manucha, W. (2020) Vitamin D Deficiency in African Americans Is Associated with a High Risk of Severe Disease and Mortality by SARS-CoV-2. Journal of Human Hypertension, 35, 378-380. https://doi.org/10.1038/s41371-020-00398-Z

[27] Vaduganathan, M., Vardeny, O., Michel, T., McMurray, J.J.V., Pfeffer, M.A. and Solomon, S.D. (2020) Renin-Angiotensin-Aldosterone System Inhibitors in Patients with COVID-19. The New England Journal of Medicine, 382, 1653-1659. 
https://doi.org/10.1056/NEJMsr2005760

[28] de Mello Pinto, M., Silva, C., Sampaio, A., Baron, M., Sancho, A., Fortuny, E., Silva, L., Picariello, F. and de Carvalho, R. (2020) Photodynamic Therapy with Phthalomethyl D: Perspectives against SARS-CoV-2. Journal of Biosciences and Medicines, 8, 104-116. https://doi.org/10.4236/jbm.2020.810010 